\title{
Life Transitions and Life Satisfaction During Young Adulthood
}

\author{
Malgorzata Switek $^{1} \cdot$ Richard A. Easterlin $^{1}$ (D)
}

Published online: 18 November 2016

(C) The Author(s) 2016. This article is published with open access at Springerlink.com

\begin{abstract}
In Sweden the overall life satisfaction trajectory between ages 22 and 40 is slightly hill-shaped and dominated by life transitions, especially those relating to one's family situation. Among persons in their twenties, partnership formation and birth of a child typically lead to a slight increase in overall satisfaction with life. Between ages 30 and 40 average life satisfaction declines, chiefly due to the increasing strains of family life and the breakup of couples. These strains are evident in data relating to specific aspects of family life. After age 30 satisfaction with one's partner declines, and so does satisfaction with both one's mother and father. Also, despite rising income, satisfaction with one's economic situation lessens. Considered as a whole, the evidence suggests that even in a welfare state the strains on young adults of balancing work and family life are substantial. The analysis is based on panel data, 1999-2009, that focus especially on family life.
\end{abstract}

Keywords Life satisfaction · Formation of unions · Parenthood · School-to-work transition · Dissolution of unions · Work-family balance

\section{Introduction}

Early adulthood is marked by a succession of major life events-completing school, leaving home, finding a job, finding a partner, starting a family. The interest here is in the effect of such events on feelings of personal well-being. Does the transition from school to work, for example, raise or lower personal happiness? What is the effect on well-being of forming a union? Of having a child? What is the overall course of subjective well-being

Richard A. Easterlin

easterl@usc.edu

Malgorzata Switek

mac.switek@gmail.com

1 Department of Economics, University of Southern California, Los Angeles, CA 90089-0253, USA 
(SWB) during young adulthood, and to what extent do these life transitions, taken as a whole, shape the well-being trajectory? These are the principal questions to which this paper is addressed. The data are from a Swedish panel study of young adults. We find, among other things, that SWB follows a slight hill-shaped trajectory to about age 40, and that life transitions play a major role in shaping this trajectory. Among the transition events, changing family circumstances are especially important.

The analysis of well-being and its association with young adult transitions is at the intersection of demography, psychology, and economics. In demography, studies of transitions in the young adulthood years are generally situated in the context of life course analysis (Elder 1998; Elder et al. 2003; Shanahan 2000; Vogel 2002). Links to feelings of well-being, however, are rarely considered. The main transitions are leaving the parental household, completing education, labor force entry, partnership formation, and the birth of the first child (Billari 2001; Hogan and Aston 1986; Marini 1984). The effects on wellbeing of all of these transitions are examined here except for leaving the parental household, an event that typically occurs before the age span covered by the present data. In addition, we study the well-being effect of dissolution of partnerships, including partnerships both with and without children.

Studies of the life course of SWB have been primarily done by economists and psychologists. Virtually all prior research focuses on the entire adult life span. The most widely-publicized finding in economic research, that of a U-shaped trajectory, implies that SWB trends downward to about age 50 and then recovers (Blanchflower and Oswald 2008; Dolan et al. 2008; Layard et al. 2012). This finding, however, describes the course of SWB holding life circumstances constant. It assumes, among other things, that as one ages, no changes occur in employment, partnership, and parental status. In contrast, in the present analysis the interest is specifically in the effect on SWB of changes in such circumstances.

Studies that follow SWB over the life cycle, taking account of changing life circumstances, are quite scarce. The findings, which typically span an entire life cycle, suggest a mild increase or stability in SWB in early adulthood followed by a decline in later life (Charles et al. 2001; Costa et al. 1987; Easterlin 2006; Mroczek and Spiro 2005). None of this work, however, considers the extent to which the overall trajectory of SWB might reflect the various life transitions examined here.

A considerable amount of research has been done on the effects on well-being of specific life events. Partnership formation has typically been found to increase life satisfaction; dissolution to decrease it (Clark et al. 2008; Lucas 2005; Musick and Bumpass 2012; Waite and Lehrer 2003; Waite et al. 2009; Zimmerman and Easterlin 2006). Results on the effect of parenting on SWB have been somewhat mixed (Kohler et al. 2005; Hansen 2012; Herbst and Ifcher 2014; McLanahan and Adams 1987). The newest insights, obtained in longitudinal studies, indicate that an increase in life satisfaction takes place right before the birth of the first child, and persists though at a declining rate over the next 2 years (Baranowska and Matysiak 2011; Clark et al. 2008; Myrskyla and Margolis 2014). The effect on SWB of the school-to-work transition has been much less studied than the effects of partnerships and parenting. An Australian study finds that there is no change in SWB for those who enter the labor market and become fully employed (Creed et al. 2003). In all of these studies, the focus is typically on a single life transition and no controls are included for other transition events. This paper adds to this earlier work by estimating the effect on well-being of each transition while controlling for other transitions, as well as controlling for time-invariant factors and time-varying life circumstances. In addition, the present study describes the typical sequence and number of transitions experienced. Also, 
using domain analysis, it throws light on the underlying mechanisms through which a given life transition such as parenting affects well-being.

\section{Methods}

\subsection{Instrument and Participants}

The instrument here is a questionnaire, the Swedish Young Adults Panel Study (YAPS), developed by demographer Eva Bernhardt of Stockholm University. The YAPS inquiry is a nationally representative longitudinal survey of three cohorts of Swedish young adults, born, respectively, in 1968, 1972, and 1976, and interviewed in 1999, 2003, and 2009. Statistics Sweden was in charge of the fieldwork, collecting data via mail and web questionnaires. Survey respondents are linked to the Swedish Register to obtain complementary information on marital status, education, year of birth, and income. The panel database contains data on a total of about 3500 individuals. The present analysis is limited to the roughly 1400 persons who answered the questions of interest here in all three survey years. Descriptive statistics for the sample are given in Appendix Tables 6 and 7. For details on the data set and publications resulting therefrom, see $<$ http://www.suda.su.se/ yaps/Index.en.html>.

\subsection{Variable Description}

Life satisfaction is the measure of SWB used as the dependent variable. It is the answer to the question: "Are you satisfied or dissatisfied with life in general right now?" Response categories are scaled from 1 to 5, with 1 meaning very dissatisfied and 5 very satisfied.

Other satisfaction variables included here relate to specific aspects of life, so-called "domain satisfaction" variables. The domains include satisfaction with economic situation, with "what you are currently doing", and also with various family relationships-partner, mother, and father. We relabel "satisfaction with what you are currently doing" as "satisfaction with work." For most respondents, "work" is a job, but for half or less of those ages 22 and 26 it refers to school. The questions on family relationships have somewhat fewer observations because those without a living mother, father, or partner did not answer the question. Satisfaction with children was not asked. The response scale for the domain satisfaction variables is $1-5$, the same as that for life satisfaction.

The main independent variables are those identifying people as going through the school-to-work, first partnership union, parenting, and partnership dissolution transitions in each of the two periods under analysis, 1999-2003 and 2003-2009. Leaving the parental household is not included here because $93 \%$ of the respondents when first interviewed were no longer living with their parents.

A high proportion of young adults in Sweden briefly interrupt their education soon after high school to engage in either work or leisure activities before re-entering education at the post-secondary level (Cook and Furstenberg 2002). Those who interrupt their education are considered here to go through the school-to-work transition only after they re-enter education and graduate with their highest degree attained, that is, after they complete their highest level of education. Partnership formation is defined as transitioning from single person living alone to married or cohabiting during either of the two periods under analysis. The two partnership states, married and cohabiting, are combined here, because 
regression analysis indicated that they have similar positive effects on life satisfaction (cf. also Musick and Bumpass 2012). The parenting transition is considered to take place with the arrival of the first child (either biological or adopted) in a respondent's household. Finally, partnership dissolution occurs when a respondent reports being in a partnership (marriage or cohabitation) in 1999 or 2003, and being single or divorced/widowed in a subsequent survey.

Other variables in the analysis include work income (adjusted for inflation), occupation, and age of the respondent's children. The surveys were done between March and May of each year; hence the satisfaction levels reported in the survey are linked to the previous year's income. Occupational categories are constructed by combining two survey questions: main activity, defining the person's employment status; and main occupation, defining the person's production sector/occupation. Child's age is derived from the year of birth of each child reported by the respondent. We view the present analysis as a first step and combine both genders to obtain an overall picture. Clearly, future work should look at males and females separately. Appendix Table 8 provides additional detail on the variables and their construction.

\subsection{Procedure}

The survey dates for the three cohorts enable us to identify four age intervals: 22-26, 26-30/32, 30-34/36, and 34-40. Where possible, cohorts with observations spanning approximately the same age interval are pooled. For example, respondents born in 1972 interviewed in 1999 and 2003 (at ages 26 and 30) were pooled with those born in 1976 interviewed in 2003 and 2009 (at ages 26 and 32) to construct the 26-30/32 age interval.

Life satisfaction of individual $i$ at age $a$ may be expressed as:

$$
L S_{i a}=\alpha_{a}+\delta_{i}+\beta X_{i a}+\varepsilon_{i a},
$$

where $\alpha_{a}$ is the association of life satisfaction with age, $\delta_{i}$ is an individual fixed effect, $X_{i a}$ is a vector of covariates that change with age, and $\varepsilon_{i a}$ is an error term. The individual fixed effect term in (1) includes the effects on life satisfaction of personal characteristics that are time-invariant, such as personality and cohort. Applying a first difference to (1) yields:

$$
\Delta L S_{i a}=\Delta \alpha_{a}+\beta \Delta X_{i a}+\Delta \varepsilon_{i a},
$$

where $\Delta L S_{i a}=\left(L S_{i a}-L S_{i a-1}\right)$. In Eq. (2), $\delta_{i}$, representing all time invariant traits, is automatically subtracted from the equation. Previous studies have recognized the importance of controlling for cohort effects when studying SWB over the life cycle (Easterlin 2006; Blanchflower and Oswald 2008). By using first differences, this paper goes a step further and eliminates not only the effect on life satisfaction of year of birth, but also the effects of other time invariant traits.

In Eq. (2), $\Delta \alpha_{a}$ captures the association between the age interval $a-1$ to $a$ and overall life satisfaction. Because $\Delta \alpha_{a}$ is age-specific, different age intervals may have a different association with life satisfaction. To estimate the average path of life satisfaction during young adulthood, a regression is run with the change in individual life satisfaction as the dependent variable, and the four age interval dummies as independent variables. Tests for possible effects of time trends and time-varying cohort effects did not change the results reported here.

The regression is an OLS first-difference model without a constant, which is methodologically equivalent to an OLS first-difference regression that includes a constant but 
omits one of the age intervals from the estimation. Since no specific socio-economic control variables are used, the coefficient on each age interval dummy represents the average experienced life satisfaction change of respondents over that interval. An econometric controversy about using OLS without a constant centers on diagnostic measures, such as $R^{2}$, which are not the main interest of this study (cf. Eisenhaur 2003).

To estimate the effect of specific life transitions on young adults' life satisfaction, regression (2) is run including the transitions undergone by each individual as explanatory variables, i.e.,

$$
\Delta L S_{i a}=\Delta \alpha_{a}+\beta_{T}^{\prime} T_{i a}+\Delta \varepsilon_{i a},
$$

where $T_{i a}$ is a matrix of dummy variables with value 1 if person $i$ has gone through transition $\mathrm{T}$ in the interval from $a-1$ to $a$, and 0 otherwise. Matrix $T_{i a}$ includes partnership formation, the school-to-work transition, parenting (with child below age 2 at time of interview), parenting (with child 2 years or older at time of interview), partnership dissolution (with a child), and partnership dissolution (without a child). Matrix $\mathrm{T}$ also includes a dummy variable for those not currently going through any transitions but who have completed their school-to-work, partnership, and parenting transitions. In this specification, the age interval coefficients capture the association between age and life satisfaction for the omitted category (those not going through any transition in an interval, and who have not completed the school-to-work, partnership, and parenting transitions) as well as the effects of age-varying factors common to all transition status groups. Since all transitions are included simultaneously, the coefficient $\beta_{T}$ captures the association between each transition and life satisfaction, controlling for the effects of all other transitions. Also controlled are the effects of age-invariant traits [see the discussion of Eq. (2) above], and of age-varying factors common to all transition status groups. Some changes in agevarying factors may be integral to a life transition, e.g., the school-to-work and partnership transitions typically entail a change in income. The effects on life satisfaction of such changes are included in $\beta$.

The next step of the analysis aims to identify how various life domains are associated with each of the four young adult transitions. The domains include satisfaction with economic situation, work, and housing, as well as satisfaction with relationships with partner, mother, and father. The association between the various life transitions and each domain is estimated using specification (3) with each domain as the dependent variable and all age intervals pooled.

Finally, the life satisfaction change for each person is predicted using only the association of life satisfaction with the transitions occurring in each person's life (that is, using coefficients $\beta_{T}$ to predict the change in life satisfaction at the individual level). The estimates for the respondents are then averaged to obtain the predicted average life satisfaction change for each age interval.

\subsection{Attrition}

Of the 2820 young adults originally interviewed in 1999, the number included in the present analysis is somewhat less than 1400. Such a high attrition rate (around 50\%) is not uncommon in panel data for developed countries (Abraham et al. 2006; Becketti et al. 1988). Attrition could be a problem in the present study if a specific sub-group of the people going through a life transition were both more likely to attrit and to experience disparate change in life satisfaction. 
It is not possible, of course, to test whether attrition is associated with a disparate change in life satisfaction for the people who leave the survey. But it is possible to compare for an earlier period the life satisfaction of those who eventually attrit with those who do not. Thus, we compare for attrits and non-attrits in 2009 the change in life satisfaction between 1999 and 2003, by regressing life satisfaction change 1999-2003 on 2009 attrition (Fitzgerald et al. 1998). If attrition were in fact a problem, then the coefficient on attrition in such a regression should be significant. The result of our regression indicates that attrition is not a significant correlate of life satisfaction change. Repeating the analysis for the domain satisfaction variables yields the same result. This analysis, so far as it goes, suggests that attrition bias is not a major problem in the present study.

\section{Results}

\subsection{Overall Life Satisfaction in Early Adulthood}

Life satisfaction between ages 22 and 40 displays a slight hill-shape. From age 22 to 30/32 life satisfaction increases, with the increase being steepest between 26 and 30/32; thereafter life satisfaction declines in each of the two age intervals studied here. This pattern is found in a regression analysis for all cohorts pooled, in which the average change in life satisfaction during each age interval is captured by the coefficient on the age interval's dummy (Table 1, column 1). As shown in Fig. 1 the cohort of 1976 is the basis for the change observed between ages 22 and 26; the cohorts of 1972 and 1976, for the change from 26 to 30/32; the cohorts of 1968 and 1972, for the change, ages 30-34/36; and finally, the cohort of 1968 for the change from $34 / 36$ to age 40. There is a difference among cohorts in the level of life satisfaction, but in each of the two intermediate age intervals, where more than one cohort is included, the direction of change is the same for each cohort. Although by the usual test $(t$ stat $\geq 2.0)$ the age coefficients are not statistically significant, this is probably because there is considerable variation among individuals in the timing of life transitions, as shown in the next section.

Figure 2 displays the average path of life satisfaction in young adulthood based on all cohorts combined. It is derived using the coefficients from the pooled regression, and adjusting life satisfaction at age 22 to zero to eliminate cohort level effects. Adding

Table 1 Change in life satisfaction in specified age interval by cohort (based on OLS regression)

\begin{tabular}{|c|c|c|c|c|}
\hline & $\begin{array}{l}\text { (1) } \\
\text { All cohorts }\end{array}$ & $\begin{array}{l}(2) \\
1976 \\
\text { Cohort }\end{array}$ & $\begin{array}{l}(3) \\
1972 \\
\text { Cohort }\end{array}$ & $\begin{array}{l}(4) \\
1968 \\
\text { Cohort }\end{array}$ \\
\hline Age $22-26$ & $0.038(0.82)$ & $0.038(0.83)$ & & \\
\hline Age $26-30 / 32$ & $0.053(1.62)$ & $0.046(1.02)$ & $0.06(1.31)$ & \\
\hline Age $30-34 / 36$ & $-0.032(0.92)$ & & $-0.017(0.38)$ & $-0.049(0.93)$ \\
\hline Age $34-40$ & $-0.034(0.66)$ & & & $-0.34(0.64)$ \\
\hline Observations & 2650 & 954 & 926 & 770 \\
\hline $\mathrm{R}^{2}$ & 0.002 & 0.002 & 0.002 & 0.002 \\
\hline
\end{tabular}

Absolute value of $t$ statistic in parentheses 


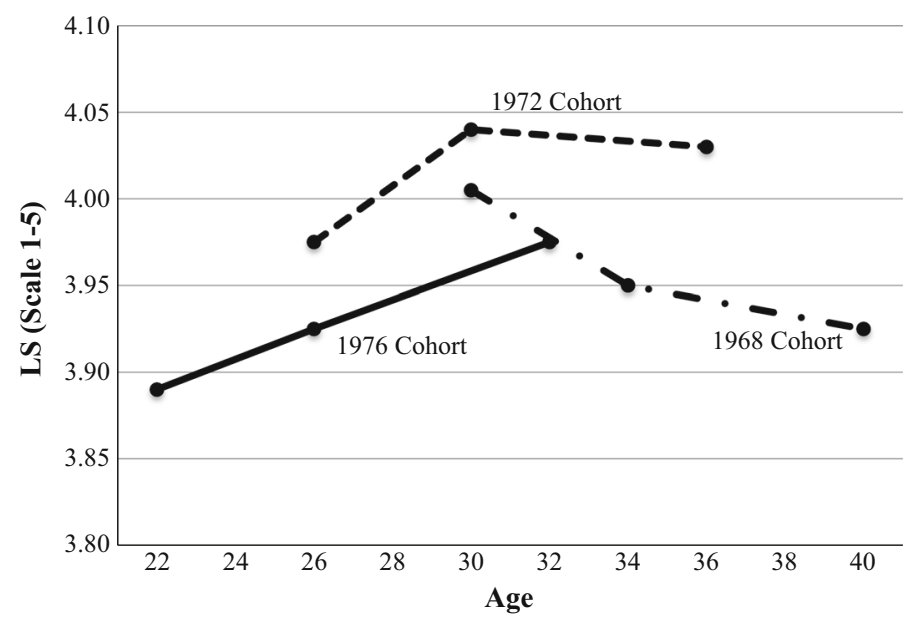

Fig. 1 Life satisfaction by age, cohorts of 1968, 1972, and 1976

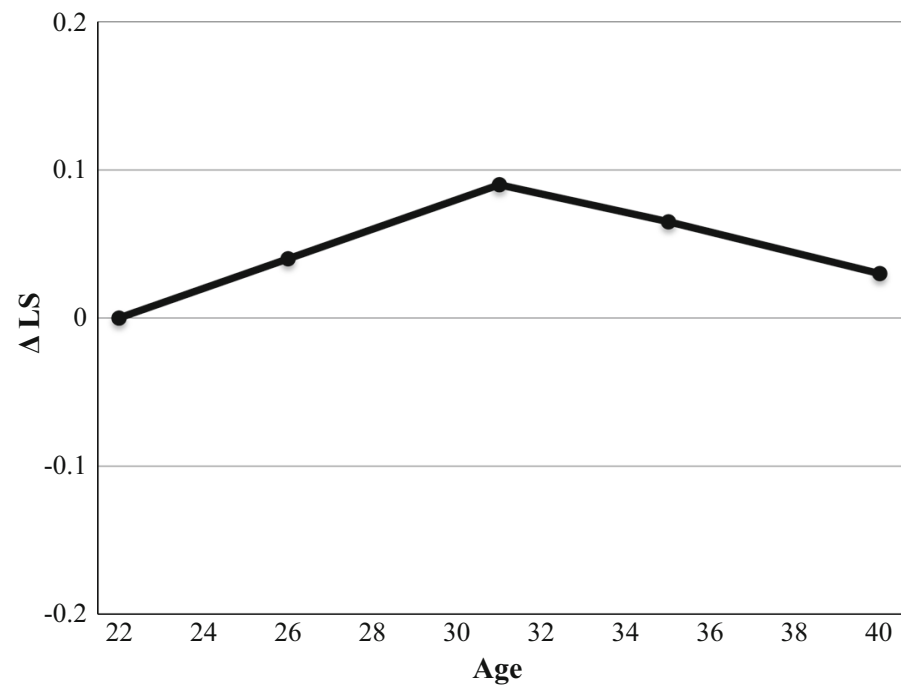

Fig. 2 Average change in life satisfaction from age 22 (3 cohorts pooled)

together the increments in the first two age segments, one finds that the overall increase in life satisfaction between ages 22 and $30 / 32$ is approximately 0.09 points; between ages $30-40$ life satisfaction decreases by about 0.07 points (Table 1 , column 1 ). As will be seen, life transitions, to which we now turn, by themselves largely predict this pattern.

\subsection{Sequence and Frequency of Life Transitions}

For the majority of respondents partnerships are formed and jobs started before ages 30/32 (Table 2, columns 1 and 2, lines 1-2). Parenting typically comes a little later, between ages 26 and 34/36 (columns 2 and 3, line 3). There is, however, considerable variation among 
Table 2 Percentage of respondents with indicated life transition during specified age interval

Some respondents undergo more than one transition during an age interval (cf. T.3, lines 3-4), and are accordingly counted here under each transition experienced in that interval

\begin{tabular}{lrrrr}
\hline Life transition & \multicolumn{1}{l}{$\begin{array}{l}\text { (1) } \\
\text { Age interval }\end{array}$} & (3) & (4) \\
\cline { 2 - 5 } & $22-26$ & $26-30 / 32$ & $30-34 / 36$ & $34-40$ \\
\hline 1. School to work & 38 & 25 & 13 & 10 \\
2. Partnership formation & 29 & 22 & 13 & 10 \\
3. Parenting & 14 & 33 & 23 & 9 \\
4. Partnership dissolution & 7 & 6 & 8 & 8 \\
(a) No children & 7 & 3 & 4 & 2 \\
(b) With children & 0 & 3 & 4 & 6 \\
Number of observations & 477 & 940 & 848 & 385 \\
\hline
\end{tabular}

Table 3 Percentage of respondents experiencing one or more of three life transitions ${ }^{\mathrm{a}}$ in specified age interval

\begin{tabular}{lllll}
\hline Number of transitions & $\begin{array}{l}(1) \\
\text { Age interval }\end{array}$ & $(2)$ & $(3)$ & (4) \\
\cline { 2 - 5 } & $22-26$ & $26-30 / 32$ & $30-34 / 36$ & $34-40$ \\
\hline 1. None & 34 & 36 & 54 & 69 \\
(a) Previously completed 0-2 & 32 & 23 & 17 & 12 \\
(b) Previously completed all 3 & 2 & 13 & 37 & 57 \\
2. One & 45 & 44 & 35 & 25 \\
3. Two & 21 & 19 & 11 & 6 \\
4. Three & 1 & 2 & 1 & - \\
\hline
\end{tabular}

School-to-work, partnership formation, parenting

respondents in the number of life transitions experienced in a given age interval. In any single 4-5 year interval between ages 22 and 30 most respondents typically experience only one transition (Table 3, line 2). But by their mid-thirties, more than half have completed the school-to-work, partnership, and parenting transitions (Table 3, column 4, line 1b). Hence, the impact on SWB of these three transitions tends to be concentrated mostly before young adults reach their mid-thirties. Partnership dissolution is fairly constant across the age range-reported by $6-8 \%$ of respondents in each age interval (Table 2 , line 4). In the early years, there are few partnerships in which the break-up of partnership involves children; toward the end of the age span, however, partnerships with children predominate among those breaking up (Table 2, lines $4 \mathrm{a}$ and $4 \mathrm{~b}$ ).

\subsection{Effect on SWB of Each Transition}

Life transitions have a strong and statistically significant effect on SWB. Indeed, taken together they predict the slight hill-shape of overall SWB, as will be shown in the following section.

SWB tends to increase significantly when a union is formed and when a couple has a baby. SWB declines significantly when infants grow into young children and when a partnership is dissolved. The transition from school-to-work appears to have no significant effect on SWB. These are the principal findings from the multiple regression for all age 
intervals pooled reported in Table 4. Additional analysis indicated that the nil result for the school-to-work transition holds separately for manual and white collar workers, and also for less-educated compared with more-educated persons. In regressions for individual age intervals (not shown here) the results are essentially the same for those age intervals in which the specified transition typically occurs.

A sense of the "why" of some of the relationships between life satisfaction and the individual transitions is suggested by similar multiple regressions for satisfaction with each of the individual domains included in the survey. Not surprisingly, partnership formation is accompanied by a large positive increase in satisfaction with one's partner (Table 5, column 4, line 1). But it is noteworthy that there is also a significant positive impact on feelings about one's economic situation, housing, and parents (columns 1, 3, 5, 6). Satisfaction with work, however, is negatively associated with partnership formation. A conjecture worth investigating is that work interferes with new conjugal relationships.

The increase in life satisfaction accompanying a new infant is presumably associated with a positive increase in satisfaction with one's children, although satisfaction with children was not asked in the survey. Interestingly, having an infant is associated with a significant decrease in satisfaction with one's mother (the infant's grandmother) (Table 5, column 5 , line $3 a)$.

As an infant grows older parenting is clearly accompanied by increasing financial and family strains. Parenting of those with children 2 or more years old is associated with a significant decrease in satisfaction with one's economic situation and with all of one's family relationships_ not just mother, but also father, and, most notably, one's partner (Table 5, line 3b).

Table 4 Change in life satisfaction associated with specified life transition status all age intervals pooled ${ }^{\mathrm{a}}$ (multiple regression coefficient)

Variable

Life satisfaction

$\begin{array}{ll}\text { Life transition status } & \\ \text { 1. Partnership formation } & 0.292(5.58)^{* *} \\ \text { 2. School-to-work } & -0.023(0.45) \\ \text { 3a. Parenting (child <2 years) } & 0.245(3.49)^{* *} \\ \text { 3b. Parenting (child 2+ years) } & -0.129(2.13)^{*} \\ \text { 4a. Partnership diss. (with child) } & -0.343(3.25)^{* *} \\ \text { 4b. Partnership diss. (no child) } & -0.099(0.9) \\ \text { 5. Transitions 1-3 completed } & -0.135(2.38)^{*} \\ \text { Age 22-26 } & -0.041(0.75) \\ \text { Age 26-30/32 } & 0.018(0.39) \\ \text { Age 30-34/36 } & 0.002(0.04) \\ \text { Age 34-40 } & 0.044(0.68) \\ \text { Observations } & 2650 \\ \mathrm{R}^{2} & 0.03\end{array}$

Absolute value of t-statistic in parentheses

The age interval coefficient is the reference group's average change in life satisfaction in that interval and reflects factors common to all transition status groups in that interval

+ Significant at $10 \%$; significant at $5 \%$;* significant at $1 \%$

a The reference group for lines 1-5 is persons who during a given age interval are those in Table 3, line 1a 
Table 5 Change in satisfaction with specified domain associated with specified life transition status, all age intervals pooled ${ }^{\mathrm{a}}$ (multiple regression coefficient)

\begin{tabular}{|c|c|c|c|c|c|c|}
\hline \multirow[t]{3}{*}{ Variable } & \multicolumn{6}{|c|}{ Satisfaction with: } \\
\hline & \multirow{2}{*}{$\begin{array}{l}\text { Economic } \\
\text { situation }\end{array}$} & \multirow[t]{2}{*}{ Work } & \multirow[t]{2}{*}{ Housing } & \multicolumn{3}{|c|}{ Family Relationships } \\
\hline & & & & Partner & Mother & Father \\
\hline \multicolumn{7}{|l|}{ Life transition status } \\
\hline $\begin{array}{l}\text { 1. Partnership } \\
\text { formation }\end{array}$ & $\begin{array}{l}0.222 \\
\quad(3.65)^{* * *}\end{array}$ & $\begin{array}{l}-0.166 \\
(2.41)^{*}\end{array}$ & $\begin{array}{l}0.148 \\
\quad(2.24)^{*}\end{array}$ & $\begin{array}{l}0.38 \\
\quad(5.73)^{* *}\end{array}$ & $\begin{array}{l}0.103 \\
\quad(2.19)^{*}\end{array}$ & $\begin{array}{l}0.113 \\
(2.04)^{*}\end{array}$ \\
\hline 2. School-to-work & $\begin{array}{l}0.599 \\
\quad(10.24)^{* *}\end{array}$ & $\begin{array}{l}-0.195 \\
\quad(2.94)^{* *}\end{array}$ & $\begin{array}{l}0.028 \\
\quad(0.43)\end{array}$ & $\begin{array}{l}0.083 \\
\quad(1.36)\end{array}$ & $\begin{array}{r}-0.049 \\
(1.09)\end{array}$ & $\begin{array}{l}-0.01 \\
\quad(0.18)\end{array}$ \\
\hline $\begin{array}{l}\text { 3a. Parenting } \\
\text { (child < } 2 \text { yr) }\end{array}$ & $\begin{array}{r}-0.069 \\
(0.85)\end{array}$ & $\begin{array}{l}0.093 \\
\quad(1.01)\end{array}$ & $\begin{array}{l}0.15 \\
(1.70)^{+}\end{array}$ & $\begin{array}{r}-0.029 \\
(0.38)\end{array}$ & $\begin{array}{l}-0.137 \\
(2.20)^{*}\end{array}$ & $\begin{array}{r}-0.034 \\
(0.46)\end{array}$ \\
\hline $\begin{array}{l}\text { 3b. Parenting (child } \\
2+\text { years) }\end{array}$ & $\begin{array}{l}-0.171 \\
(2.43)^{*}\end{array}$ & $\begin{array}{l}0.027 \\
\quad(0.34)\end{array}$ & $\begin{array}{r}-0.073 \\
(0.96)\end{array}$ & $\begin{array}{l}-0.181 \\
\quad(2.64) * *\end{array}$ & $\begin{array}{l}-0.161 \\
(2.93)^{* *}\end{array}$ & $\begin{array}{l}-0.141 \\
(2.17)^{*}\end{array}$ \\
\hline $\begin{array}{l}\text { 4a. Partnership diss. } \\
\text { (with child) }\end{array}$ & $\begin{array}{l}-0.443 \\
(3.62)^{* *}\end{array}$ & $\begin{array}{l}-0.297 \\
(2.15)^{*}\end{array}$ & $\begin{array}{r}-0.208 \\
(1.55)\end{array}$ & $\begin{array}{r}-0.157 \\
(1.28)\end{array}$ & $\begin{array}{l}0.059 \\
\quad(-0.63)\end{array}$ & $\begin{array}{l}0.202 \\
(1.76)^{+}\end{array}$ \\
\hline $\begin{array}{l}\text { 4b. Partnership diss. } \\
\text { (no child) }\end{array}$ & $\begin{array}{r}-0.216 \\
(1.69)^{+}\end{array}$ & $\begin{array}{r}-0.085 \\
(0.59)\end{array}$ & $\begin{array}{c}-0.221 \\
\quad(1.6)\end{array}$ & $\begin{array}{l}-0.403 \\
\quad(2.89)^{* *}\end{array}$ & $\begin{array}{l}0.065 \\
\quad(0.66)\end{array}$ & $\begin{array}{r}-0.023 \\
(0.20)\end{array}$ \\
\hline $\begin{array}{l}\text { 5. Transitions 1-3 } \\
\text { completed }\end{array}$ & $0.099(1.51)$ & $\begin{array}{l}-0.204 \\
(2.75)^{* *}\end{array}$ & $\begin{array}{r}-0.01 \\
\quad(0.15)\end{array}$ & $\begin{array}{l}0.008 \\
\quad(0.12\end{array}$ & $\begin{array}{r}-0.045 \\
(0.87)\end{array}$ & $\begin{array}{r}-0.015 \\
(0.25)\end{array}$ \\
\hline Age $22-26$ & $\begin{array}{c}-0.108 \\
(1.74)^{+}\end{array}$ & $\begin{array}{l}0.127 \\
\quad(1.81)^{+}\end{array}$ & $\begin{array}{l}0.012 \\
\quad(0.17)\end{array}$ & $\begin{array}{r}-0.065 \\
(0.92)\end{array}$ & $\begin{array}{l}-0.108 \\
\quad(2.25)^{*}\end{array}$ & $\begin{array}{l}-0.113 \\
(2.02)^{*}\end{array}$ \\
\hline Age $26-30 / 32$ & $\begin{array}{l}0.133 \\
\quad(2.57)^{*}\end{array}$ & $\begin{array}{l}0.137 \\
\quad(2.34)^{*}\end{array}$ & $\begin{array}{l}0.233 \\
\quad(4.15)^{* *}\end{array}$ & $\begin{array}{c}-0.09 \\
\quad(1.61)\end{array}$ & $\begin{array}{r}-0.056 \\
(1.42)\end{array}$ & $\begin{array}{l}-0.127 \\
(2.69)^{* *}\end{array}$ \\
\hline Age $30-34 / 36$ & $\begin{array}{l}0.111 \\
\quad(1.99)^{*}\end{array}$ & $\begin{array}{l}0.236 \\
\quad(3.74)^{* *}\end{array}$ & $\begin{array}{l}0.115 \\
(1.89)^{+}\end{array}$ & $\begin{array}{l}-0.161 \\
\quad(2.72)^{* * *}\end{array}$ & $\begin{array}{l}-0.091 \\
(2.10)^{*}\end{array}$ & $\begin{array}{l}-0.124 \\
(2.38)^{*}\end{array}$ \\
\hline Age $34-40$ & $0.113(1.52)$ & $\begin{array}{l}0.284 \\
\quad(3.36)^{* *}\end{array}$ & $0.12(1.48)$ & $\begin{array}{l}-0.246 \\
(3.24)^{* *}\end{array}$ & $\begin{array}{r}-0.059 \\
(1.00)\end{array}$ & $\begin{array}{r}-0.03 \\
(0.42)\end{array}$ \\
\hline Observations & 2632 & 2579 & 2629 & 1933 & 2500 & 2301 \\
\hline $\mathrm{R}^{2}$ & 0.09 & 0.01 & 0.03 & 0.05 & 0.02 & 0.02 \\
\hline
\end{tabular}

Absolute value of t-statistic in parentheses

a The reference group for lines $1-5$ is persons who during a given age interval are those in Table 3 , line 1 a. The age interval coefficient is the reference group's average change in life satisfaction in that interval and reflects factors common to all transition status groups in that interval

+ Significant at $10 \%$; significant at $5 \%$;* significant at $1 \%$

There is an interesting difference between partnerships with and without children in the domain changes associated with the break-up of a partnership. For those with a child, partnership dissolution is accompanied by decreased satisfaction with both work and one's economic situation (Table 5, line 4a). For those who are childless, dissolution is associated with decreased satisfaction with one's partner and one's economic situation (Table 5, line $4 b)$.

As noted earlier, the school-to-work transition has no significant impact on life satisfaction. The domain results hint at why this may be so. Taking a job is accompanied by a significant improvement in feelings about one's economic situation, but also a significant decline in satisfaction with work (Table 5, line 2). Possibly schoolwork is less onerous than the demands of a steady job. 


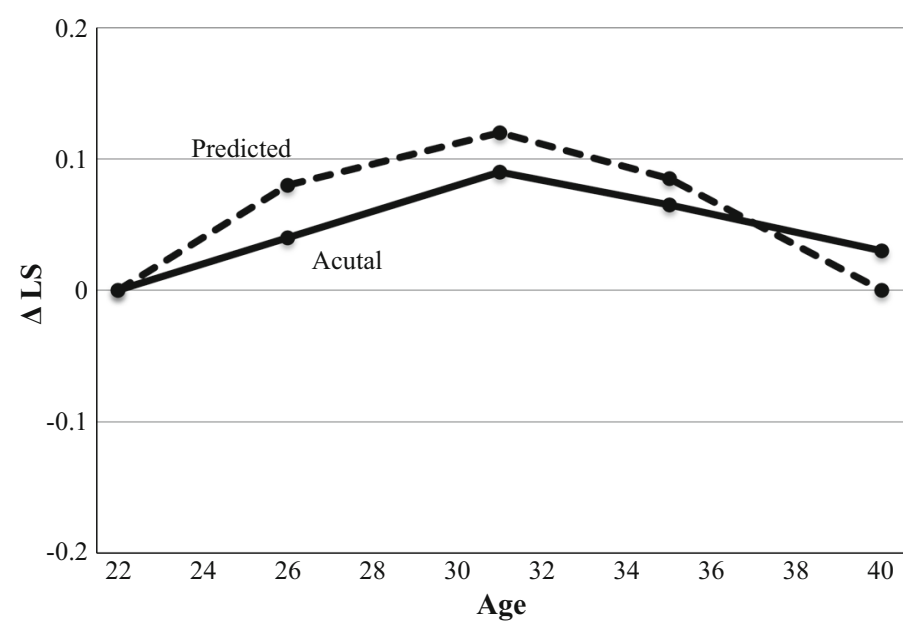

Fig. 3 Average change in life satisfaction from age 22, actual and predicted

\subsection{Effect of Transitions on the Overall Course of Life Satisfaction}

Let us suppose that the only factors affecting each respondent's life satisfaction during young adulthood are the transitions studied here. What, then, would be the average course of life satisfaction for all respondents combined? To answer this the life satisfaction change for each respondent in each age interval is predicted based only on the transitions experienced by the respondent in that interval. The magnitude of each transition's impact on life satisfaction is given by the regression coefficients in Table 4, column 1.

The predicted course of life satisfaction based only on transition events is a slight hillshaped trajectory similar to the actual course of life satisfaction (Fig. 3). The predicted change is somewhat larger, especially in the beginning and ending age intervals, but the age at which the maximum is reached is correctly identified. In cross section micro-economic regressions with life satisfaction as the dependent variable, changes in life circumstances such as income and health are typically found to influence life satisfaction significantly (Layard et al. 2012). The fact that such effects are excluded from the present prediction (other than those directly entailed in a transition) suggests that transition events are especially important in shaping the overall trajectory of life satisfaction in young adulthood.

\section{Discussion}

Our principal findings are that in Sweden young adults' feelings of overall well-being typically increase slightly to about age 30 , and then decline by almost the same amount in the following 10 years. The increase is largely due to the positive and statistically significant impact on life satisfaction arising from partnership formation and birth of a first child. The subsequent decline reflects in large part the growing financial and family strains arising from parenthood, which significantly affect well-being. Among parents with a child older than 2 years, satisfaction with one's economic situation, partner, mother, and father all decline significantly. The effect on life satisfaction of each life transition is estimated holding other transitions constant, and with controls for both time-invariant traits such as personality, and time-varying factors such as income and health. The effect of a time-varying factor linked directly to a given 
transition (e.g., income change associated with the school-to-work and partnership transitions) is included in the estimated effect of the transitions. The results suggest that in Sweden life transition events like partnership formation and parenthood largely dominate other life circumstances in determining the life satisfaction trajectory in young adulthood.

The slight hill-shape of overall life satisfaction to age 40 is contrary to the U-shaped life cycle trajectory reported in economic research. The difference in results is doubtless due to the fact that the U-shaped finding is based on regressions that hold life circumstances constant, while the finding here is, in fact, due directly to a change in life circumstances, specifically, forming unions and having a baby. Clearly, if one wants to know what actually happens to life satisfaction as people progress through the life cycle, it is necessary to take such changes in life circumstances into account.

The life cycle trajectory found here is reasonably consistent with previous life cycle studies that do take account of life circumstances, but the present result differs in suggesting an earlier downturn in life satisfaction-at around age 30 rather than middle-age. It is possible that the typical course of life satisfaction over the full life cycle is, in fact, more variable than that identified in previous studies that, by using quadratic curve fitting, ruled out more nuanced patterns.

The findings here on the effects on well-being of life transitions such as parenting and union formation and dissolution are novel in that the effect of each transition is estimated holding the effects of other transitions constant. Nevertheless the results are much the same as those reported in studies that focus on the effect on well-being of a single transition. It is noteworthy that the present findings on the links between life satisfaction and parenting are consistent with those recently reported in other work (Clark et al. 2008; Baranowska and Matysiak 2011; Myrskyla and Margolis 2014).

The present results are based on panel data for Swedish young adults in the first decade of this century. Sweden is typically viewed as a welfare state, par excellence, with cradle-to-grave public policies. Almost all women of working age are in the labor force, and the majority of new mothers are back at work by a year after childbirth (Evertsson and Duvander 2011). A majority of children under three are in publicly-funded child care (Statistics Sweden 2012). Family childcare such as that provided by grandmothers is significantly limited because most women are likely to be working into their early sixties. The finding here that satisfaction with one's mother declines significantly for those with a new infant may well be linked to the high labor force participation of older women. New parents may expect the infant's grandmother(s) to share the burden of child care, and the limited ability of working grandmothers to help may be a disappointment.

These results on the nature and determinants of young adults' life satisfaction demonstrate the value of overall measures of SWB as well as those relating to specific life domains. On a website of the European Union devoted to disseminating information about policies to help children and families, Sweden is celebrated as a role model of "successful reconciliation of work and family life" (Europa 2015). That Swedish young adults in their thirties experience, on average, a slight decline in feelings of well-being, and that family relationships play an important part in this decline, suggests that even in Sweden successful reconciliation of work and family roles may still have some way to go. There is need for much more study of the link between the work-family nexus and SWB.

Acknowledgements We are grateful to Shaked Peleg for assistance and for comments to Eva Bernhardt, Robson Morgan, and Kelsey J. O'Connor. Financial assistance was provided by the University of Southern California.

Open Access This article is distributed under the terms of the Creative Commons Attribution 4.0 International License (http://creativecommons.org/licenses/by/4.0/), which permits unrestricted use, distribution, and reproduction in any medium, provided you give appropriate credit to the original author(s) and the source, provide a link to the Creative Commons license, and indicate if changes were made. 


\section{Appendix}

See Tables 6, 7 and 8.

Table 6 Descriptive statistics, satisfaction variables, by age interval and age

\begin{tabular}{|c|c|c|c|c|c|c|c|c|}
\hline \multirow{3}{*}{ Variable } & \multirow{2}{*}{\multicolumn{2}{|c|}{$\begin{array}{l}(1) \quad(2) \\
\text { Age interval, } 22-26\end{array}$}} & \multirow{2}{*}{\multicolumn{2}{|c|}{$\begin{array}{l}\text { (3) (4) } \\
\text { Age interval, } \\
26-30 / 32\end{array}$}} & \multirow{2}{*}{\multicolumn{2}{|c|}{$\begin{array}{l}(5) \quad(6) \\
\text { Age interval, } \\
30-34 / 36\end{array}$}} & \multirow{2}{*}{\multicolumn{2}{|c|}{$\begin{array}{l}\text { (7) } \\
\text { Age interval, } 34-40\end{array}$}} \\
\hline & & & & & & & & \\
\hline & 22 & 26 & 26 & $30 / 32$ & 30 & $34 / 36$ & 34 & 40 \\
\hline \multicolumn{9}{|c|}{ Mean satisfaction with: } \\
\hline Life & 3.89 & 3.93 & 3.95 & 4.01 & 4.03 & 3.99 & 3.96 & 3.92 \\
\hline $\begin{array}{l}\text { Economic } \\
\text { situation }\end{array}$ & 2.91 & 3.06 & 3.12 & 3.40 & 3.32 & 3.51 & 3.38 & 3.58 \\
\hline Housing & 3.56 & 3.60 & 3.64 & 3.91 & 3.90 & 4.02 & 3.93 & 4.05 \\
\hline Work & 3.80 & 3.80 & 3.84 & 3.88 & 3.84 & 3.94 & 3.86 & 3.98 \\
\hline $\mathrm{N}$ & $470-477$ & $467-477$ & $925-940$ & $929-940$ & $834-848$ & $841-848$ & $381-385$ & 376-385 \\
\hline \multicolumn{9}{|c|}{ Mean satisfaction with: } \\
\hline Mother & 4.33 & 4.21 & 4.27 & 4.17 & 4.25 & 4.13 & 4.14 & 4.06 \\
\hline $\mathrm{N}$ & 467 & 468 & 917 & 898 & 813 & 791 & 363 & 354 \\
\hline Father & 4.01 & 3.97 & 4.05 & 3.91 & 3.91 & 3.84 & 3.78 & 3.78 \\
\hline $\mathrm{N}$ & 467 & 448 & 886 & 861 & 772 & 720 & 327 & 298 \\
\hline Partner & 4.42 & 4.48 & 4.49 & 4.46 & 4.52 & 4.36 & 4.44 & 4.27 \\
\hline $\mathrm{N}$ & 316 & 368 & 721 & 800 & 713 & 745 & 329 & 331 \\
\hline
\end{tabular}

Table 7 Descriptive statistics, socio-economic variables, by age interval and age

\begin{tabular}{|c|c|c|c|c|c|c|c|c|}
\hline \multirow[t]{2}{*}{ Variable } & \multicolumn{2}{|c|}{$\begin{array}{l}(1) \quad(2) \\
\text { Age interval, } \\
22-26\end{array}$} & \multicolumn{2}{|c|}{$\begin{array}{l}(3) \\
\text { Age interval, } \\
26-30 / 32\end{array}$} & \multicolumn{2}{|c|}{$\begin{array}{l}(5) \\
\text { Age interval, } \\
30-34 / 36\end{array}$} & \multicolumn{2}{|c|}{$\begin{array}{l}(7) \quad(8) \\
\text { Age interval, } \\
34-40\end{array}$} \\
\hline & 22 & 26 & 26 & $30 / 32$ & 30 & $34 / 36$ & 34 & 40 \\
\hline Mean work income (SEK, 000) & 69.3 & 140.8 & 134.8 & 198.2 & 177.3 & 222.5 & 211.3 & 270.7 \\
\hline Active in labor force $\mathrm{a}^{\mathrm{a}}(\%)$ & 42.2 & 66.5 & 66.0 & 79.6 & 74.1 & 86.7 & 80.2 & 96.7 \\
\hline Prof., high exec. (\%) & 1.1 & 12.7 & 11.7 & 20.5 & 15.2 & 20.3 & 16.4 & 25.9 \\
\hline Student $(\%)$ & 48.4 & 21.8 & 20.5 & 6.5 & 8.0 & 4.5 & 6.8 & 1 \\
\hline Single $(\%)$ & 61.6 & 39.6 & 40.1 & 22.4 & 25.1 & 16.5 & 20.8 & 15.8 \\
\hline In partnership (\%) & 38.2 & 59.7 & 59.3 & 75.5 & 72.5 & 78.3 & 74.8 & 76.6 \\
\hline Divorced widowed (\%) & 0.2 & 0.6 & 0.6 & 2.0 & 2.4 & 5.2 & 4.4 & 7.5 \\
\hline Parenting (with partner) (\%) & 4.0 & 17.4 & 20.0 & 50.5 & 46.2 & 65.8 & 62.3 & 66.8 \\
\hline Single parent $(\%)$ & 0.8 & 1.3 & 1.7 & 3.9 & 4.5 & 8.1 & 9.1 & 13.5 \\
\hline Mean child per respondent & 0.07 & 0.24 & 0.31 & 0.87 & 0.83 & 1.37 & 1.28 & 1.49 \\
\hline Final ed. $=$ postsecondary $(\%)$ & 65.0 & & 60.3 & & 52.5 & & 48.8 & \\
\hline Male $(\%)$ & 41.9 & & 41.0 & & 41.9 & & 44.2 & \\
\hline Birth cohort $1976(\%)$ & 100.0 & & 50.8 & & 0.0 & & 0.0 & \\
\hline
\end{tabular}


Table 7 continued

\begin{tabular}{|c|c|c|c|c|c|c|c|c|}
\hline \multirow[t]{2}{*}{ Variable } & \multicolumn{2}{|c|}{$\begin{array}{l}\text { Age interval, } \\
22-26\end{array}$} & \multicolumn{2}{|c|}{$\begin{array}{l}\text { Age interval, } \\
26-30 / 32\end{array}$} & \multicolumn{2}{|c|}{$\begin{array}{l}\text { Age interval, } \\
30-34 / 36\end{array}$} & \multicolumn{2}{|c|}{$\begin{array}{l}\text { Age interval } \\
34-40\end{array}$} \\
\hline & 22 & 26 & 26 & $30 / 32$ & 30 & $34 / 36$ & 34 & 40 \\
\hline Birth cohort $1972(\%)$ & 0.0 & & 49.3 & & 54.6 & & 0.0 & \\
\hline Birth cohort $1968(\%)$ & 0.0 & & 0.0 & & 45.4 & & 100.0 & \\
\hline $\mathrm{N}$ & 477 & & 940 & & 848 & & 385 & \\
\hline
\end{tabular}

${ }^{a}$ Excludes students, those unemployed, those in labor market programs (e.g. adult learning), those on parental leave, and inactive

Table 8 Variable description

\begin{tabular}{|c|c|c|}
\hline Variable & Question asked & Response categories \\
\hline \multicolumn{3}{|c|}{ Satisfaction variables } \\
\hline Life satisfaction & $\begin{array}{l}\text { "Are you satisfied or dissatisfied with life in } \\
\text { general right now?" }\end{array}$ & $\begin{array}{l}\text { Scale } 1-5 \text { with } 1 \text {-very dissatisfied, and } \\
5=\text { very satisfied }\end{array}$ \\
\hline $\begin{array}{l}\text { Financial } \\
\text { satisfaction }\end{array}$ & $\begin{array}{l}\text { "Are you satisfied or dissatisfied with your } \\
\text { economic situation in general right now?" }\end{array}$ & $\begin{array}{l}\text { Scale } 1-5 \text { with } 1-\text { very dissatisfied, and } \\
5=\text { very satisfied }\end{array}$ \\
\hline $\begin{array}{l}\text { Satisfaction } \\
\text { with work }\end{array}$ & $\begin{array}{l}\text { "Are you satisfied or dissatisfied with what } \\
\text { you are currently doing?" }\end{array}$ & $\begin{array}{l}\text { Scale } 1-5 \text { with } 1-\text { very dissatisfied, and } \\
5=\text { very satisfied }\end{array}$ \\
\hline $\begin{array}{l}\text { Satisfaction } \\
\text { with housing }\end{array}$ & $\begin{array}{l}\text { "Are you satisfied or dissatisfied with your } \\
\text { housing situation?" }\end{array}$ & $\begin{array}{l}\text { Scale } 1-5 \text { with } 1 \text {-very dissatisfied, and } \\
5=\text { very satisfied }\end{array}$ \\
\hline $\begin{array}{l}\text { Satisfaction } \\
\quad \text { with partner }\end{array}$ & $\begin{array}{l}\text { "Are you satisfied or dissatisfied with your } \\
\text { relationship with your partner?" }\end{array}$ & $\begin{array}{l}\text { Scale } 1-5 \text { with } 1 \text {-very dissatisfied, and } \\
5=\text { very satisfied }\end{array}$ \\
\hline $\begin{array}{l}\text { Satisfaction } \\
\text { with mother }\end{array}$ & $\begin{array}{l}\text { "Are you satisfied or dissatisfied with your } \\
\text { relationship with your mother?" }\end{array}$ & $\begin{array}{l}\text { Scale } 1-5 \text { with } 1 \text {-very dissatisfied, and } \\
5=\text { very satisfied }\end{array}$ \\
\hline $\begin{array}{l}\text { Satisfaction } \\
\text { with father }\end{array}$ & $\begin{array}{l}\text { "Are you satisfied or dissatisfied with your } \\
\text { relationship with your father?" }\end{array}$ & $\begin{array}{l}\text { Scale } 1-5 \text { with } 1 \text {-very dissatisfied, and } \\
5=\text { very satisfied }\end{array}$ \\
\hline \multicolumn{3}{|c|}{ Transition variables and variables used for their construction } \\
\hline $\begin{array}{l}\text { School-to-work } \\
\text { transition } \\
99-03 \\
(03-09)\end{array}$ & $\begin{array}{l}\text { Dummy variable taking the value } 1 \text { if the } \\
\text { respondent achieved his or her highest } \\
\text { level of education in between } 1999 \text { and } \\
2003 \text { (2003 and 2009) }\end{array}$ & $\begin{array}{l}0 \text { - other } \\
1 \text {-completed school-to-work transition } \\
\text { in } 99-03(03-09)\end{array}$ \\
\hline $\begin{array}{l}\text { Partnership } \\
\text { formation } \\
99-03 \\
(03-09)\end{array}$ & $\begin{array}{l}\text { Dummy variable taking the value } 1 \text { if the } \\
\text { respondent went from being single living } \\
\text { alone in } 1999 \text { (2003) to being in a } \\
\text { marriage or cohabitation in } 2003 \text { (2009) }\end{array}$ & $\begin{array}{l}0 \text {-other } \\
1 \text { - experienced partnership formation } \\
\text { in } 99-03(03-09)\end{array}$ \\
\hline $\begin{array}{l}\text { Parenting } \\
\text { transition } \\
99-03 \\
(03-09)\end{array}$ & $\begin{array}{l}\text { Dummy variable taking the value } 1 \text { if the } \\
\text { respondent had the first biological or } \\
\text { adoptive child born in 1999-2003 } \\
\text { (2003-2009) (see below for parent status } \\
\text { construction); and } 0 \text { otherwise }\end{array}$ & $\begin{array}{l}0 \text { - other } \\
1 \text {-completed parenting transition in } \\
99-03(03-09)\end{array}$ \\
\hline
\end{tabular}


Table 8 continued

\begin{tabular}{|c|c|c|}
\hline Variable & Question asked & Response categories \\
\hline $\begin{array}{l}\text { Partnership } \\
\text { dissolution } \\
99-03 \\
(03-09)\end{array}$ & $\begin{array}{l}\text { Dummy variable taking the value } 1 \text { if the } \\
\text { respondent went from being in a marriage } \\
\text { or cohabitation in } 1999 \text { ( } 2003 \text { ) to being } \\
\text { single living alone, divorced or widowed } \\
\text { (including divorced/widowed cohabiting) } \\
\text { in } 2003 \text { (2009) }\end{array}$ & $\begin{array}{l}0 \text { - other } \\
1 \text { - experienced partnership dissolution } \\
\text { in } 99-03(03-09)\end{array}$ \\
\hline Marital status & $\begin{array}{l}\text { Marital status from Swedish register which } \\
\text { classifies people as single, married, } \\
\text { divorced or widowed, combined with self- } \\
\text { reported information on cohabiting }\end{array}$ & $\begin{array}{l}\text { 1. Single living alone; } 2 \text {. single } \\
\text { cohabiting; } 3 \text {. married; } 4 \text {. divorced or } \\
\text { widowed living alone; } 5 \text {. divorced or } \\
\text { widowed cohabiting }\end{array}$ \\
\hline Education level & $\begin{array}{l}\text { Education level from the Swedish register } \\
\text { data }\end{array}$ & $\begin{array}{l}\text { Compulsory } 9 \text { years; secondary } \\
<3 \text { years; secondary } 3 \text { years; post- } \\
\text { secondary }<3 \text { years; post-secondary } \\
\geq 3 \text { years/postgraduate }\end{array}$ \\
\hline \multirow[t]{9}{*}{ Parent status } & 1999 survey: & $\begin{array}{l}\text { Based on the answers to the YAPS } \\
\text { questions }\end{array}$ \\
\hline & $\begin{array}{l}\text { Q36a_1-Q36c_1: Year of birth, biological } \\
\text { child 1-3 }\end{array}$ & $\begin{array}{l}\text { Respondents were classified in the } \\
\text { following parent categories: }\end{array}$ \\
\hline & $\begin{array}{l}\text { Q36a_4-Q36c_4: Year of birth, other child } \\
\text { 1-3 }\end{array}$ & $\begin{array}{l}\text { 1. Non-parents (no children born by } \\
\text { 2009) }\end{array}$ \\
\hline & 2003 Survey: & $\begin{array}{l}\text { 2. Parents in } 2009 \text { (first child born in } \\
2003-2009 \text { ) }\end{array}$ \\
\hline & $\begin{array}{l}\text { Q37a_1-Q37d_1: Year of birth, child 1-4 } \\
\text { living in household }\end{array}$ & $\begin{array}{l}\text { 3. Parents in } 2003 \text { and } 2009 \text { (first child } \\
\text { born in 1999-2003, more children } \\
\text { born in 2003-2009) }\end{array}$ \\
\hline & $\begin{array}{l}\text { Q37a_4-Q37d_4: Child 1-4 is: respondent's } \\
\text { and partner's child, respondent's but not } \\
\text { partner's child, partner's but not } \\
\text { respondent's child, adoptive child, foster- } \\
\text { child }\end{array}$ & $\begin{array}{l}\text { 4. Parents in } 2003 \text { not } 2009 \text { (first child } \\
\text { born in 1999-2003, no children born } \\
\text { in 2003-2009) }\end{array}$ \\
\hline & 2009 Survey: & \\
\hline & $\begin{array}{l}\text { F20a1_ar_IP-F20a5_ar_IP: Year of birth, } \\
\text { biological or adoptive child } 1-5\end{array}$ & \\
\hline & $\begin{array}{l}\text { F20d1_IP-F20d5_IP: Does the child live } \\
\text { with you? }\end{array}$ & \\
\hline \multicolumn{3}{|l|}{ Other variables } \\
\hline Cohort & Register data for year person was born & 1968,1972 , or 1976 \\
\hline Gender & Register data for gender of person surveyed & Male or female \\
\hline Work income & $\begin{array}{l}\text { Register information on "income from work } \\
\text { before tax" for the years 1998, 2002, and } \\
2008 \text { (in thousands of SEK) }\end{array}$ & $\begin{array}{l}\text { Real thousands of SEK, adjusted for } \\
\text { inflation in } 2002 \text { and } 2008 \text { using the } \\
\text { CPI index from Sweden Statistics }\end{array}$ \\
\hline
\end{tabular}


Table 8 continued

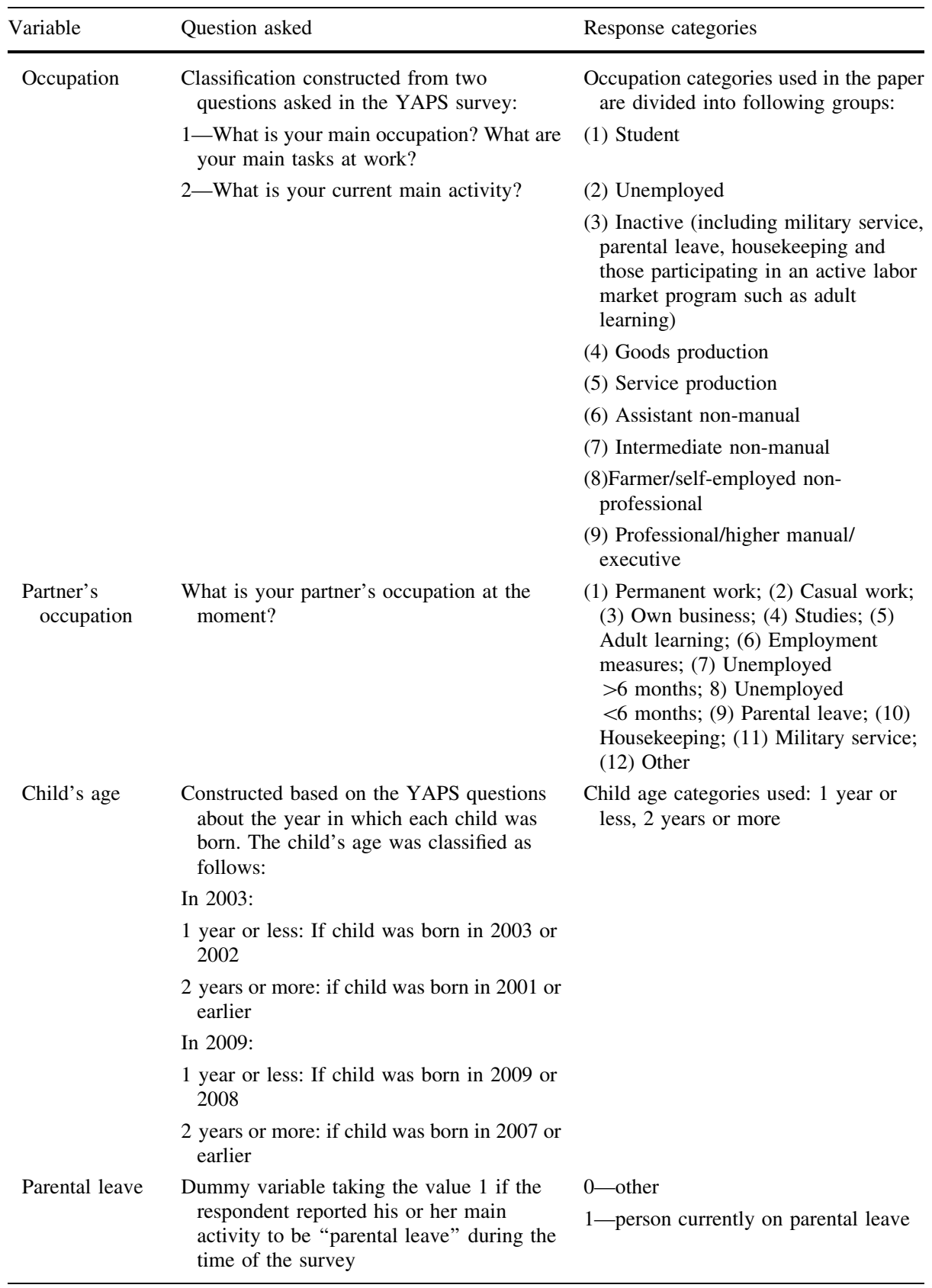


Table 8 continued

\begin{tabular}{|c|c|c|}
\hline Variable & Question asked & Response categories \\
\hline \multirow[t]{4}{*}{$\begin{array}{l}\text { Respondent's } \\
\text { age }\end{array}$} & \multirow{4}{*}{$\begin{array}{l}\text { Age based on the register data for birth } \\
\text { cohort and on the year survey was } \\
\text { conducted }\end{array}$} & $\begin{array}{l}\text { Age assigned as follows for each birth } \\
\text { cohort: }\end{array}$ \\
\hline & & $\begin{array}{l}1968 \text { cohort: } 30 \text { in } 1999,34 \text { in } 2003,40 \\
\text { in } 2009\end{array}$ \\
\hline & & $\begin{array}{l}1972 \text { cohort: } 26 \text { in } 1999,30 \text { in } 2003,36 \\
\text { in } 2009\end{array}$ \\
\hline & & $\begin{array}{l}1976 \text { cohort: } 22 \text { in 1999, } 26 \text { in 2003, } 30 \\
\text { in } 2009\end{array}$ \\
\hline
\end{tabular}

\section{References}

Abraham, K. G., Maitland, A., \& Bianchi, S. M. (2006). Nonresponse in the American time use survey: Who is missing from the data and how much does it matter? Public Opinion Quarterly, 70(Special Issue No. 5), 676-703.

Baranowska, A., \& Matysiak, A. (2011). Does parenthood increase happiness? Evidence for Poland. Vienna Yearbook of Population Research, 9, 307-325.

Becketti, S., Gould, W., Lillard, L., \& Welch, F. (1988). The panel study of income dynamics after fourteen years: An evaluation. Journal of Labor Economics, 6(4), 472-492.

Billari, F. C. (2001). The analysis of early life courses: Complex descriptions of the transition to adulthood. Journal of Population Research, 18(2), 119-142.

Blanchflower, D. G., \& Oswald, A. (2008). Is well-being U-shaped over the life cycle? Social Science and Medicine, 66(8), 1733-1749.

Charles, S. T., Reynolds, C. A., \& Gatz, M. (2001). Age-related differences and change in positive and negative affect over 23 years. Journal of Personality and Social Psychology, 80(1), 136-151.

Clark, A., Diener, E., Georgellis, Y., \& Lucas, R. (2008). Lags and leads in life satisfaction: A test of the baseline hypothesis. The Economic Journal, 118, F222-F243.

Cook, T. D., \& Furstenberg, F. F. (2002). Explaining aspects of the transition to adulthood in Italy, Sweden, Germany, and the United States: A cross-disciplinary, case-synthesis approach. Annals of the American Academy of Political and Social Science, 580(1), 257-287.

Costa, P. T., Jr., Zonderman, A. B., McCrae, R. R., Cornoni-Huntley, J., Bocke, B. Z., \& Barbano, H. E. (1987). Longitudinal analyses of psychological well-being in a national sample: Stability of mean levels. Journal of Gerontology, 42, 50-55.

Creed, P. A., Muller, J., \& Patton, W. (2003). Leaving high school: The influence and consequences for psychological well-being and career-related confidence. Journal of Adolescence, 26(2003), 295-311.

Dolan, P., Peasgood, T., \& White, M. (2008). Do we really know what makes us happy? A review of the economic literature on the factors associated with subjective well-being. Journal of Economic Psychology, 29, 94-122.

Easterlin, R. A. (2006). Life cycle happiness and its sources: Intersections of psychology, economics, and demography. Journal of Economic Psychology, 27, 463-482.

Eisenhaur, J. G. (2003). Regression through the origin. Teaching Statistics, 25(3), 76-80.

Elder, G. H. (1998). The life course as developmental theory. Child Development, 69(1), 1-12.

Elder, G. H., Johnson, M. K., \& Crosnoe, R. (2003). The emergence and development of life course theory. In M. T. Jeylan \& M. J. Shanahan (Eds.), Handbook of the life course (pp. 3-19). New York: Kluwer Academic Publishers.

Europa. (2015). http://europa.eu/epic/countries/sweden/index_en.thm. Accessed 28 February 2015.

Evertsson, M., \& Duvander, A.-Z. (2011). Parental leave-Possibility or trap? European Sociological Review, 27(4), 435-450.

Fitzgerald, J., Gottschalk, P., \& Moffitt, R. (1998). An Analysis of sample attrition in panel data: The Michigan Panel Study of income dynamics. NBER Technical Working Paper No. 220.

Hansen, T. (2012). Parenthood and happiness: A review of fold theories versus empirical evidence. Social Indicators Research, 108, 29-64.

Herbst, C. M, \& Ifcher, J. (2014). The increasing happiness of parents. Working Paper No. 2014-05-SCUECON. Economics Department, Leavey School of Business, Santa Clara University, Santa Clara, CA. 
Hogan, D. P., \& Aston, N. M. (1986). The transition to adulthood. Annual Review of Sociology, 12, $109-130$.

Kohler, Hans-Peter, Behrman, Jere R., \& Skytthe, Axel. (2005). Partner + children = happiness? The effects of partnerships and fertility on well-being. Population and Development Review, 31(3), 407-445.

Layard, R., Clark, A., \& Senik, C. (2012). The OECD approach to measuring subjective well-being. In J. Helliwell, R. Layard, \& J. Sachs (Eds.), World happiness report 2013 (pp. 112-137). New York: United Nations.

Lucas, R. E. (2005). Time does not heal all wounds: A longitudinal study of reaction and adaptation to divorce. Psychological Science, 26(12), 945-950.

Marini, M. M. (1984). The order of events in the transition to adulthood. Sociology of Education, 57(2), 63-84.

McLanahan, S., \& Adams, J. (1987). Parenthood and psychological well-being. Annual Review of Sociology, $13,237-257$.

Mroczek, D. K., \& Spiro, A. (2005). Change in life satisfaction during adulthood: Findings from the veterans affairs normative aging study. Journal of Personality and Social Psychology, 88(1), 189-202.

Musick, K., \& Bumpass, L. (2012). Reexamining the case for marriage: Union formation and change in well-being. Journal of Marriage and Family, 74(1), 1-18.

Myrskyla, M., \& Margolis, R. (2014). Happiness: Before and after the kids. Demography, 51, 1843-1866.

Shanahan, M. (2000). Pathways to adulthood in changing societies: Variability and mechanisms in life course perspective. Annual Review of Sociology, 26, 667-692.

Statistics Sweden. (2012). Women and men in Sweden: Facts and figures 2012. Orebro: SCB-Tryck.

Vogel, J. (2002). European welfare regimes and the transition to adulthood: A comparative and longitudinal perspective. Social Indicators Research, 59(3), 275-299.

Waite, L., \& Lehrer, E. (2003). The benefits from marriage and religion in the United States: A comparative analysis. Population and Development Review, 29(2), 255-275.

Waite, L., Luo, Y., \& Lewin, A. C. (2009). Marital happiness and marital stability: Consequences for psychological well-being. Social Science Research, 38(1), 201-212. 